\title{
Exploring the Impact of Transformation to Fully Online Learning During COVID-19 on Malaysian University Students' Academic Life and Performance
}

\author{
https://doi.org/10.3991/ijim.v15i05.20203 \\ Nabil Hasan Al-Kumaim ${ }^{(\varpi)}$ \\ Universiti Teknikal Malaysia Melaka (UTeM), Melaka, Malaysia \\ nhs1426@yahoo.com \\ Fathey Mohammed \\ Universiti Utara Malaysia (UUM), Sintok, Malaysia \\ Nadhmi A. Gazem \\ Taibah University, Medina, KSA \\ Yousef Fazea \\ Universiti Utara Malaysia, Sintok, Malaysia \\ Abdulsalam K. Alhazmi \\ University of Science and Technology, Aden, Yemen \\ Omar Dakkak \\ Karabük University, Karabük, Turkey
}

\begin{abstract}
The COVID-19 pandemic has forced many organizations in the world to fully utilize variety of emerging online communication platform technologies. Higher Education Institutions (HEIs) are among these organizations that obliged students and instructors to use different online communication platforms to insure uninterrupted education process. However, the COVID-19 pandemic has generated many considerable challenges for the global higher education community while using such emerging technologies. The purpose of this study is to analyze university student's perceptions on the challenges and hurdles they face during the Covid-19 pandemic when they use IT platform applications for online learning activities. This research used mixed methods research with main emphasis on qualitative research, supported by literature content analysis techniques. The data set for this study was collected during 16th of May 2020 to 5th of Jun 2020. Based on the descriptive analysis and the analyzed results using NVivo12 for the data that was collected from 486 students from different universities in Malaysia, students disclosed various obstacles they encounter when they use IT platform applications for online learning. These obstacles are summarized as follows: (1) Work and information overload received from instructors through online learning platforms (2) Technical challenges related to students' lack of affordability for having online learning sup-
\end{abstract}


port facilities (3) Personal health challenges related to stress and anxiety problems.

Keywords - COVID-19 Pandemic, Online Learning, Emerging Technologies, Stress, Students' Performance

\section{Introduction}

In the first half of 2020, people around the world found themselves facing the pandemic of COVID-19, a strong invisible enemy that forced the majority of people to change many of their own cultural routines, including daily life routines and practices, ranged from personal practices to organizational, and outdoor or public practices. Many dramatic changes in policies have been imposed to force compliance to many countries rules and regulations as attempts to protect community members from becoming victims of this COVID-19 pandemic and to ensure the continuation of high level of productivity and performance in their societies [1]. One of these important organizations faced with dealing with COVID-19 pandemic is the University as main part of Higher Education Institutions and one of the most important service sectors that involve different level of students who represent future potential human labor force. Some university students have experience and long history in dealing with online learning platforms to engage with learning activities while others do not. Regardless of the intensity of using e-learning platforms or students' ability to use these emerging information technologies in their education journey, COVID-19 pandemic has examined academicians' level of preparation to adopt such technologies and tested the student's readiness level to use these technologies in their online learning activities [2]. Consequently, many university students during COVID-19 period found no alternatives or other options than dealing with some advanced online Information and Communication Technologies (ICT) to accomplish their learning activities and follow up with their instructors in a safe manner in order to insure social distance is maintained [3]. It is undeniable that using ICT applications enhanced by internet technologies proved to be one of the potential powerful tools that play significant role in the speedy development of e-learning [4]. Nevertheless, the full and sudden utilization of these online products during COVID-19 may have some negative effects on students' side, as a result of some hindrances which may likely hamper many students' learning process. Therefore, this study aims to analyze and expose university students' views and perceptions on using different types of emerging ICT online programs during COVID-19 pandemic. In addition, this study aims to identify the obstacles and consequence of applying full e-learning process during COVID19 from students' perspective while using these e-learning emerging technologies. 


\section{Background and Related Works}

\subsection{The of reactions toward COVID-19 pandemic}

In early 2020, the world was shocked with the sudden and rapid attack of coronavirus known as COVID-19. It was detected in December 2019 in Wuhan city in China, and has caused ongoing outbreak pandemic [5]. The first traced case was detected on 17th November 2019 in Hubei in China [6]. At the time of writing this study in August 2020, over 23,318,415 cases have been reported in 188 countries and regions, resulting in 806,630 deaths, and the going reported recovery of 15,027,662 people [7]. Therefore, on $11^{\text {th }}$ of March 2020, the World Health organization (WHO) declared COVID-19 outbreak as a global pandemic. The term pandemic is defined as "an epidemic occurring worldwide, or over a very wide area, crossing international boundaries and usually affecting a large number of people" [8].

Subsequently, Malaysia announced the first detected case of COVID19 on 25 January 2020 from a Chinese tourist. On $4^{\text {th }}$ of February 2020, Malaysia confirmed the first Malaysian case, a 41-year old man infected by COVID19 [9]. On the $16^{\text {th }}$ of March 2020, the number of positive COVID19 cases had reached 553, and the Malaysian Prime Minister Tan Sri Muhyiddin Yassin announced the first Movement Control Order (MCO) from $18^{\text {th }}$ March to $31^{\text {st }}$ March 2020 to reduce the rapid spread of COVID-19 [10, 11].

Unexpected orders by many governments around the world to follow quarantine and different phases of MCO created anxiety and panic situation. COVID-19 spread rapidly and created a panic situation that directly affected many businesses and organization systems, including the education system. Subsequently, on $27^{\text {th }}$ of May 2020, the Higher Education Ministry in Malaysia declared that all teaching and learning activities in all universities and other high education centers must be conducted through online platforms until $31^{\text {st }}$ December 2020, while waiting for further notice to be decided for year 2021. Only few exceptions for some learning activities could be physically or performed face-to-face with strict rules to follow as a necessary step for COVID19 outbreak prevention [12].

\subsection{E- Learning platforms as an emergency survival tool during COVID-19}

The process of teaching and learning using online platforms where instructors and students communicate virtually is referred to as online learning [13-15]. Since the customary face-to-face courses are not allowed during COVID-19 pandemic in obedience to the MCO imposed by government, learning through online is the only emergency survival tool during COVID-19. Practically, researchers in the field of the online distance education divide online learning into two major forms: synchronous and asynchronous distance education [16]. In the synchronous form, students attend the class virtually while the instructor teaches. The process of delivering information in synchronous form often is conducted in real time with an interactive response between instructors and students. Therefore, the online platform technologies that are 
used to serve synchronous form requires high dependence on strong internet connection, involving some necessary hardware and software to help students and instructors in using audio and video while communicating [17]. Meanwhile, asynchronous online learning form does not require students real time participation when the instructor is teaching because it can be available for students any time as recorded materials. In fact, this makes asynchronous online learning more flexible for students in terms of time. For some students, asynchronous online learning could be superior to synchronous because it gives students time to recap and analyze the knowledge they received [18].

\subsection{The status of online learning between necessity and challenges}

In this regard, Malaysian Education Ministry instructed all universities to allow students to go back home and inform them that all teaching and learning activities will be online until further notice. As a result, the only safe and relevant method to conduct online learning and teaching activities is Online Distance Learning (ODL) [19] known as e-learning. Online education is the best method for both students and educators, especially during the different, long MCO phases [20]. Universities and other public and private higher education institutions had to consider the best alternatives to ensure that education activities could continue with less contact and as high quality as possible, and online learning was the only appropriate way [21]. However, several important factors while implementing online learning technology needed to be considered by the management of these institutions, such as speed of internet connectivity, coverage and time constraints faced by both educators and students [2]. In addition, managing new normal of social and health affect will be provoked among students due to COVID-19 pandemic.

In a natural circumstance, education system is comprised of many complex elements such as instructors, students, syllabus and huge number of relevant resources and facilities that must be well developed and carefully designed to insure fruitful education outcome. Thus, it is not easy to adopt or adapt full online learning in response to a sudden pandemic such as COVID-19 without encountering many problems and challenges. Researchers have recently reported that both academic staff and students are facing multiple obstacles in conducting ODL using ICT platforms[22, 23]. These obstacles could be technical issues such as unfamiliarity with some information technologies platforms, limited internet access, insufficient experience to deal with some online learning platforms in terms of student participation, interactivity and engagement, inadequate well-designed assessment process to measure online learning outcomes and lack of experience to develop online courses content or to how transform some courses from offline to online mode. Other challenges are relevant to universities cultural aspects, low level of positive engagement during online classes by students, socially depressed learners [24]. In this regard, the following sections in this study will highlight the online learning technologies that have emerged during COVID-19 pandemic, the impact of these technologies and the observation and analysis of the COVID-19 outbreak from the students' perspectives. 


\section{Research Method and Data Collection}

This research adopted mixed method approach using both qualitative exploratory method and quantitative approach to generate descriptive analysis. Self-administrated questionnaire was designed using online Google to serve data collection purpose. Due to COVID-19 social distance rules and restrictions, online questionnaire was best choice to collect data. The online Self-administrated questionnaire was designed to include three main parts; respondent's demographic information; closed end questions that measure impact of COVID-19 on different student aspects such as social, health and personal practices; and (what and how) open-end questions. Regarding third part, respondents were provided enough writing space to express their thoughts and reveal their own experience about the subject.

The data was collected using snowballing sampling technique. "Snowball" sampling is a sampling technique in which the researcher initially samples a small group of people relevant to the research questions, and these sampled participants propose and redistribute questionnaire to other participants who have had the experience or characteristics relevant to the research topic. These participants will then suggest others and so on [25]. The total number of collected data was 486 data sets, a number which the researcher believes is sufficient to do qualitative analysis and to generate reasonable quantitative descriptive analysis. As in the qualitative research, sample sizes are recommended not to be large, as this will prevent the researcher from extracting enough rich data. At the same time, too small a sample is not recommended, as this will make it hard to reach data saturation [26-28].

\section{$4 \quad$ Results and Discussion}

\subsection{Respondents demographics information}

The statistics on demographic profile for respondents are shown in Table 1. It is shown that the percentages of male and female participants were $52.5 \%$ and $47.5 \%$, respectively. The percentage of young participants (between 21 to 23 years) was 48.7 $\%$, which constituted the largest portion of the participants. In contrast, the smallest percentage, $10.5 \%$, were 28 years and above. About $79 \%$ of the participants had a bachelor's degree, which represents the largest number of participants followed by other level of education as minor number of participants. Participants from public universities represent $92 \%$ as compared to $8 \%$ participants from private universities. As this study was conducted in Malaysia, table shows that $76 \%$ are Malaysian followed by $24 \%$ 'other', which are international participants. 
Table 1. Demographics of the respondents

\begin{tabular}{|l|l|c|c|}
\hline \multicolumn{1}{|c|}{ Demographics } & \multicolumn{1}{|c|}{ Description } & Frequency & Percentage (\%) \\
\hline \multirow{4}{*}{ Gender } & Male & 255 & 52.5 \\
\cline { 2 - 4 } & Female & 231 & 47.5 \\
\hline \multirow{5}{*}{ Age Group } & $18-20$ Years & 114 & 23.5 \\
\cline { 2 - 4 } & $21-23$ Years & 237 & 48.7 \\
\cline { 2 - 4 } & $24-27$ Years & 84 & 17.3 \\
\cline { 2 - 4 } & $28-$ older & 51 & 10.5 \\
\hline \multirow{5}{*}{ Academic Qualification } & Diploma & 35 & 7.2 \\
\cline { 2 - 4 } & Bachelor & 384 & 79 \\
\cline { 2 - 4 } & Master & 37 & 6.2 \\
\cline { 2 - 4 } & Doctorate & 447 & 7.6 \\
\hline \multirow{3}{*}{ Nationality } & Public & 39 & 92 \\
\cline { 2 - 4 } & Private & 369 & 76 \\
\hline & Malaysian & 117 & 24 \\
\cline { 2 - 4 } & Non-Malaysian & & \\
\hline
\end{tabular}

4.2 Analyzing students' online teaching methods preferences during COVID19

As shown in Figure 1, three categories of students' preferences can be identified. First, almost third (33\%) of the students' (161) preferred asynchronous online teaching method in their universities. Second, only (14\%) of the respondents preferred synchronous method. Third, a large percentage of respondents $(53 \%)$ preferred if their instructors use both methods. The finding that the third category of respondents, those who preferred to have both synchronous and asynchronous methods in online teaching, is in agreement with previous studies. Having both asynchronous and synchronous teaching methods, the active learning and content delivery were found to bemore effective and help to increase student's engagement [29]. Those students in the first category -who preferred asynchronous form on online teaching- might find it as more time flexible and cost saving and that is consistent with some previous research which indicated that asynchronous online education has a less investment cost than synchronous online education. Asynchronous online teaching also allows students to recap and analyze the knowledge they received [16, 18, 30]. 


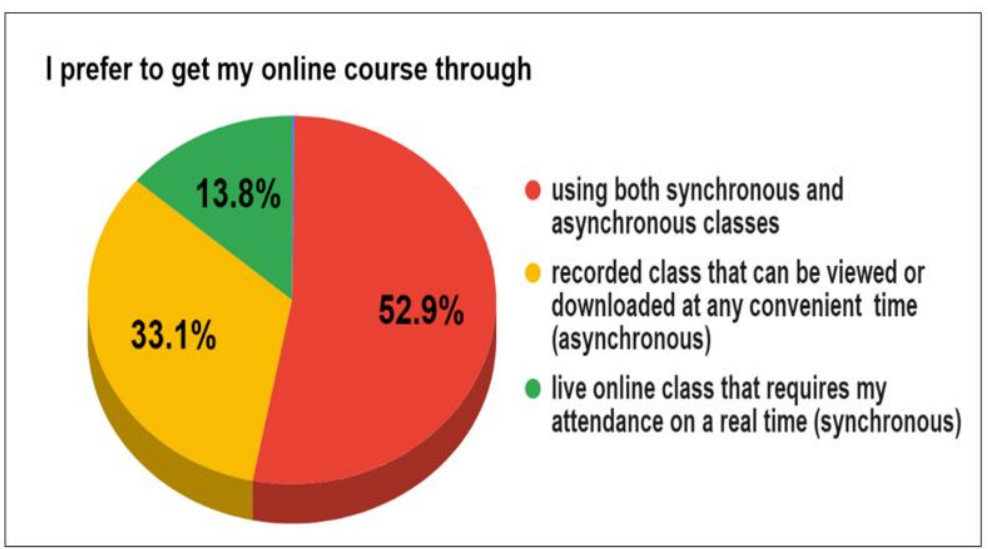

Fig. 1. Online teaching method preferences

\subsection{Online learning emerging technologies during COVID-19 pandemic}

A variety of online communication platforms were used during COVID-19 pandemic as emergency remote tools to reach out to the students for online learning activities. Training initiatives were prompted by many higher education institutions during the MCO period, and most of the universities in Malaysia organized online training for lectures and instructors to assist them in using online platforms for learning and teaching processes. As a result, students found themselves having no other option than to deal with various online learning technologies. As shown in Fig. 2 below, different online learning technologies platforms are being used in many Malaysian universities by both instructors and students. Google online platforms programs ranked highest in terms of usage $(+100 \%)$ among Malaysian institutions and students, followed by WhatsApp (64\%) as medium of communication for online learning. WebEx and Zoom programs rated as third and fourth highest online learning platforms with frequency use of (60\%) and (35\%), respectively. Surprisingly, the results revealed from this study show that the most popular social media networks such as Facebook and YouTube are not among highly used online platforms as medium of online learning and communication compared to other abovementioned four highest programs used for conducting online teaching and learning. There are two reasons why these popular social networks are not highly used in formal online learning. First, some negative impacts of integrating them in online learning process. As reported by some previous researchers, some of these negative impacts are relevant to privacy and security issues, time consumption, distraction, and ethical issues $[31,32]$. Second, there may be hurdles that hamper social media in teaching practice such as institution cultural and administrative factors [32]. 


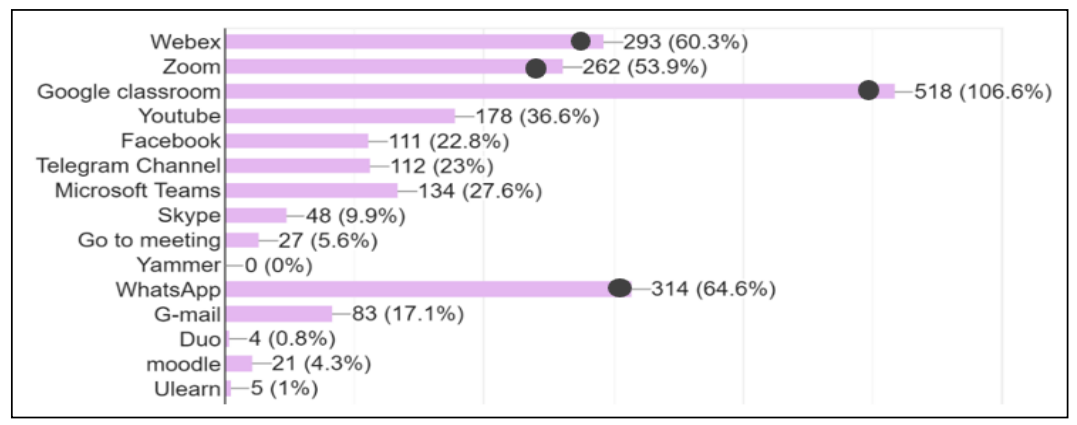

Fig. 2. Online learning technologies platforms used by student's university

As concluded by the authors of this study, Table 3 below summarizes some of the reasons why some certain information communication technologies (ICT) are highly used as an online platform for teaching and learning activities in Higher Education Institutions during COVID-19 pandemic. These reasons or factors are represented in (1) platform level of familiarity among users (2) platform simplicity design and ease of use (3) platform level of safety and privacy (4) low fees cost platforms or fully sponsored by organization (5) platform acceptable level of video \& audio quality performance (6) platform number of user's space and capacity (7) platform interactivity support features (8) storage and pickup (9) compatibility and flexibility of use.

There is no doubt that during COVID-19 pandemic, these online learning emerging technologies provide numerous assistance to both students and instructors and absolutely support different forms of distance learning and make education activities more accessible to students with more flexibility in participating, interaction, and convenience $[18,64]$.

Table 2. Factors affecting high use of certain online platform for distance education purpose

\begin{tabular}{|l|l|c|}
\hline \multicolumn{1}{|c|}{ Factor } & \multicolumn{1}{|c|}{ Definition } & $\begin{array}{l}\text { Support from literature } \\
\text { for the similar concept }\end{array}$ \\
\hline Level of familiarity & $\begin{array}{l}\text { The prior knowledge that users of online learning platform } \\
\text { have about practicing certain aspects of task, material, or } \\
\text { application. }\end{array}$ & [34],[35] \\
\hline Simplicity design \& & $\begin{array}{l}\text { The level of user-friendly interface functions designed to } \\
\text { afford high degrees of freedom in users and provide im- } \\
\text { ease of use } \\
\text { plementation of functions in the most understandable and } \\
\text { easy manner. }\end{array}$ & [36], [37],[38] \\
\hline Level of safety and & $\begin{array}{l}\text { The online platform application owned by other party will } \\
\text { not misuse or abuse user's information and communication } \\
\text { privacy }\end{array}$ & [39],[40] \\
\hline Cost saving & $\begin{array}{l}\text { The online platform is financially free or at low cost or } \\
\text { sponsored by the organization or affordable for users. }\end{array}$ & [41],[42],[43],[44],[45] \\
\hline $\begin{array}{l}\text { Audio \& video } \\
\text { quality performance }\end{array}$ & $\begin{array}{l}\text { The Audio \& video features in online platform should } \\
\text { perform efficiently to support students' study }\end{array}$ & [46],[47],[48],[49] \\
\hline capacity and space & $\begin{array}{l}\text { The ability of platform to accommodate large number of } \\
\text { users }\end{array}$ & [50],[51], [52] \\
\hline
\end{tabular}




\begin{tabular}{|l|l|c|}
\hline Interactivity features & $\begin{array}{l}\text { The online platform features can insure bidirectional } \\
\text { communication and engagement between learners, learner } \\
\text { with instructor, and learner with content. }\end{array}$ & [53],[54],[55],[56] \\
\hline $\begin{array}{l}\text { Reliable Storage } \\
\text { backup }\end{array}$ & $\begin{array}{l}\text { The ability of online platform to provide users with secure } \\
\text { and reliable storage for data sharing and transaction }\end{array}$ & [57],[58], [59],[60] \\
\hline $\begin{array}{l}\text { Compatibility and } \\
\text { flexibility of use }\end{array}$ & $\begin{array}{l}\text { The ability of online platform to integrate and work in } \\
\text { other different online platform, or function in a different } \\
\text { operating system's environment }\end{array}$ & [61],[62],[63] \\
\hline
\end{tabular}

However, the sudden fully online implementation for teaching and learning in some Malaysian universities caused students to encounter some problems and challenges that might seriously affect their academic performance and personal wellbeing. In the next sections, this study will focus more on exposing some of these problems and challenges that students face while they experience online teaching and learning during COVID-19 pandemic.

\subsection{Online learning and student's perceptions on the challenges and problems they face during COVID-19 pandemic}

During the first and second phases of movement control order (MCO) in Malaysia between ( $18^{\text {th }}$ of March to $25^{\text {th }}$ then extended from $10^{\text {th }}$ April to $28^{\text {th }}$ April), the majority of Malaysian universities began to fully conduct all classes through online learning platforms. The Ministry of Higher Education (MOHE) then declared on May 27 that all university courses must be conducted fully online, with no face-to-face teaching allowed until December 31, 2020 [12]. At the same time, many Malaysian local press and news agencies and some members in education institutions began reporting about some student complaints about the unease and challenges they experience when applying full mode of online learning $[65,66]$. Responding to these complaints and reports, the authors of this study have decided to explore more deeply the challenges and problems encountered by university students during COVID-19. By analyzing the collected data from respondents about the impact of using online learning emerging technologies during COVID-19 pandemic, number of challenges and problems were revealed and explored as discussed and explained in the next section.

Theme (I): Challenges relevant to online teaching and technical issues: This section discusses the results related to technical and online learning challenges and problems. This section has three main subthemes summarized as (a) students work overload (b) causes of students work overload (c) consequences of students work overload. The discussion for this theme and its subthemes will be supported with evidence extracted from the results of collected data and justified with relevant literature.

Work - online tasks - Overload: As shown in Figure 3 responding to one of the closed end questions from this research designed questionnaire, more than two thirds of university students $(69.5 \%)$ feel overloaded when following up with their online courses, while $(30.5 \%)$ of the students declared no overload feeling was faced. 


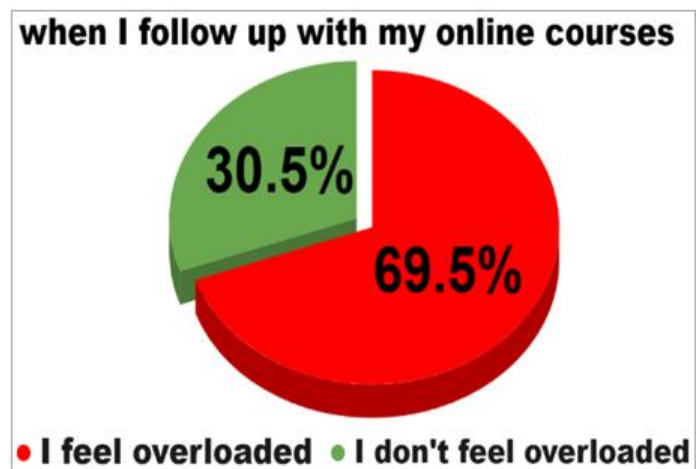

Fig. 3. Students stress feeling

This challenge could be caused by many reasons. First, the overconcern of instructors of the subjects to finish the syllabus on time, such reason was reported in previous research as the fear and panic among constructors on how to complete the program of study [2]. Second, the designed teaching plans remain unchanged although COVID-19 has forced to change the medium of teaching and communication. Third, some of the university instructors and students had insufficient experience with dealing, assessing, and managing online distance education or they have lack of training. This second reason was consistent with previous research which indicated that due to the sudden emergence of the COVID-19, some instructors and students are facing the challenges of lacking online teaching and learning experience [67]. Finally, students dealing with multiple online learning platforms could be one of the reasons for information overload that cause workload and maximize level of stress among students as further elaborated in the next subsection.

Causes of students work overload: As shown in Figure 4, when students were asked to mention the sources of overload they encounter when dealing with online courses during COVID19, $(71.4 \%)$ they refer to the dealing with many online tasks as main source of overload feeling, whereas almost (20\%) of the students consider receiving too much information from the online learning platforms as another source for them feeling overloaded. 


\section{I feel overloaded during lockdown time because of:}

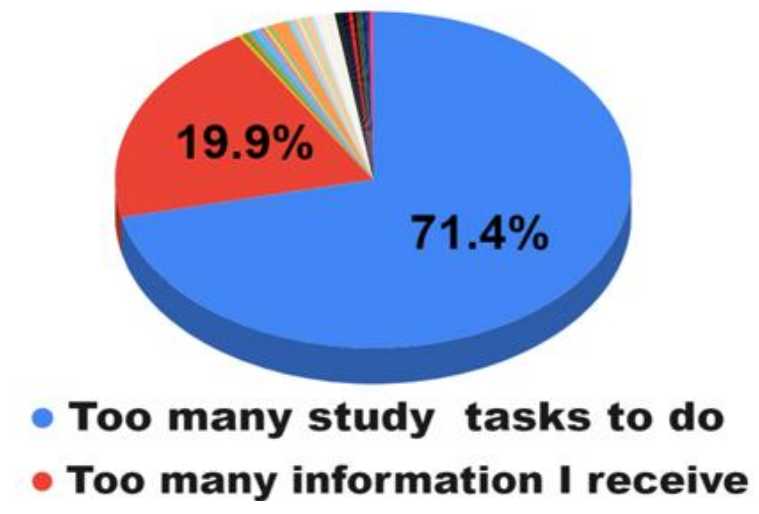

Fig. 4. Causes of student's stress

Consequences of students work overload: By seeing and comparing Figure 5 and 6 and highlighting just major percentage values, it can be said that the number of hours students spent in front of their computers before COVID-19 is not exceeding 3 hours for almost $(48 \%)$ of the students, and is not exceeding 5 hours for almost $(28 \%)$ of the students. In summary, the number of hours students spent in front of their computers before COVID-19 on average did not exceed 5 hours. On the other hand, number of hours students spent in front of their computers during COVID-19 has remarkable incremental change. For example, as shown in Figure 6, there are a number of students, $(23.7 \%),(20.4 \%)$ and $(18.5 \%)$, whose number of hours spent in front of their computers during COVID19 exceed (6,8 and 10 hours), respectively.

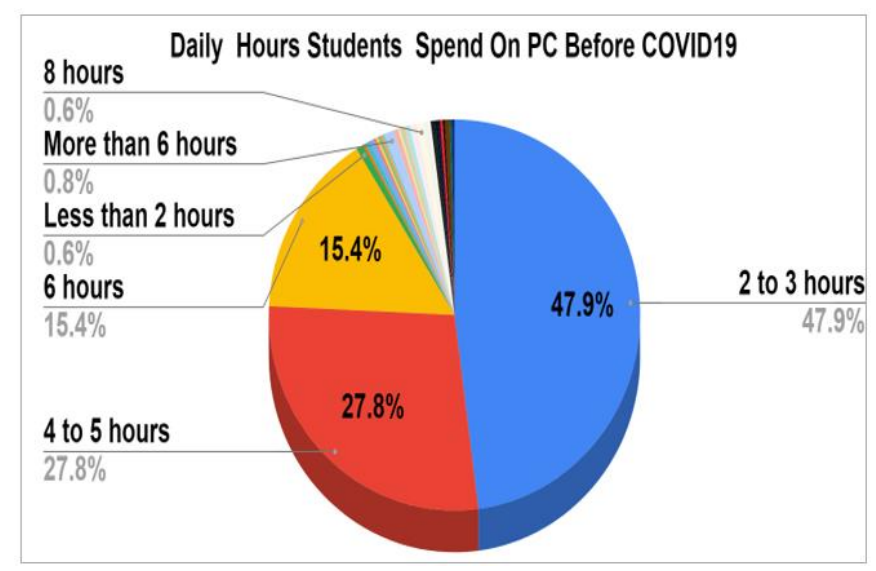

Fig. 5. Number of hours students spent on computer before COVID-19 pandemic 


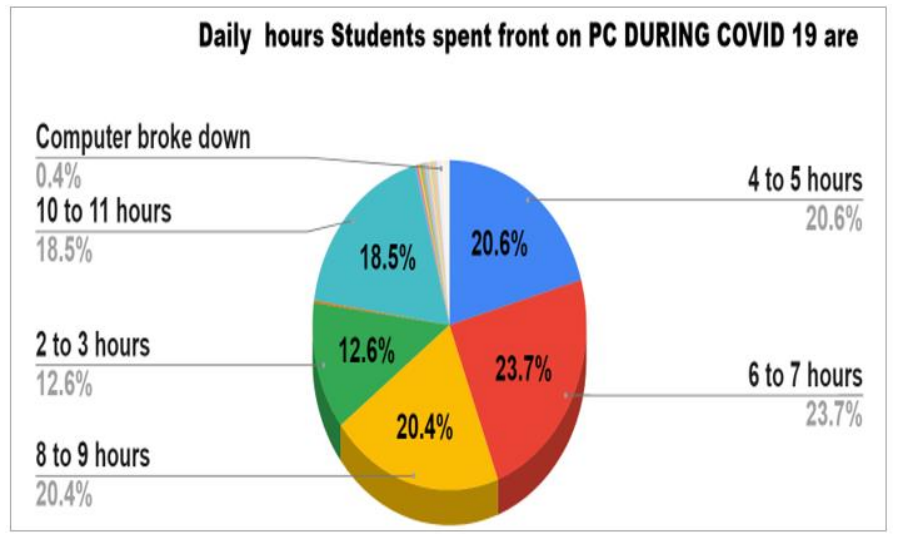

Fig. 6. Number of hours students spent on computer during COVID-19 pandemic

Although the number of incremental of hours that students spend with their computers or mobile devices during COVID-19 looks to be a normal reaction to fulfill online learning tasks, it has several critical consequences on students' side. This includes costs associated with buying more internet connection time, buying supportive hardware for online courses, increasing level of focus on subjects, having skill of time management, sacrificing some of the works inside the home, which could create extra work for other family members. In addition, students are required to deal with multiple online learning tasks that might come from different multiple online learning platforms, which may lead to sleeplessness. All these problems hamper students' academic performance and could lead students to become stressed, leading to a serious negative impact on their mental health and personal wellbeing as can be seen and explained in the challenges in next section

Theme (II): challenges relevant to Mental and Health Issues: The results of data collected from students as shown in Fig. 7 reveals that $(67 \%)$ of the students declared their feeling of stress during COVID-19 pandemic, while about (28\%) of the students declared no stress feeling was faced during COVID-19 pandemic. The number of online tasks occupying students' minds and the workload they face due to incremental number of hours they spend on online learning platforms could be one of the major reasons for stress among students. To gain a clearer vision of the causes of students' stress during COVID-19, researchers of this study have asked participants to list and describe the reasons behind their feelings of stress. 


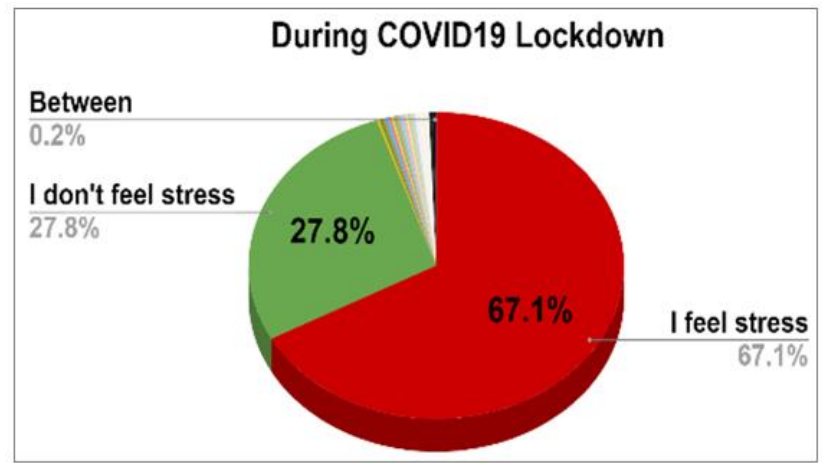

Fig. 7. Rate of students who feel stress during COVID-19

The stress problem is considered as one of the old and important hot topic phenomena among scholars and it has become a greater concern during COVID-19 pandemic due to the strong link between stress and COVID-19 outbreak. This is because the COVID-19 outbreak had widespread concerns on the increase of anxiety and stress among individuals all over the world [68]. This study is concerned with exploring students' views about their stress feelings during COVID-19 and the reasons behind their stress. This concern comes from the fact that poor health status sometimes is significantly associated with greater stress psychological impact caused by levels of stress among individuals [69].

As extracted from data collected from different Malaysian university's students, Figure 8 shows that there are five major sources of stress when students use different online learning platforms during COVID-19: 1) more than (62\%) of respondents report the pressure of having too many online tasks included in these platforms; 2) limited and weak internet connection as stated by more than $(51 \%)$ of the respondents; 3 ) more than $(51 \%)$ of students reported unfamiliarity with study environment and new normal study practice in their home; 4) (37.3\%) of students reported stress due to inadequate resources relevant to subjects they are learning; 5) (20.4\%) of the students worried they may become victim of the COVID19.

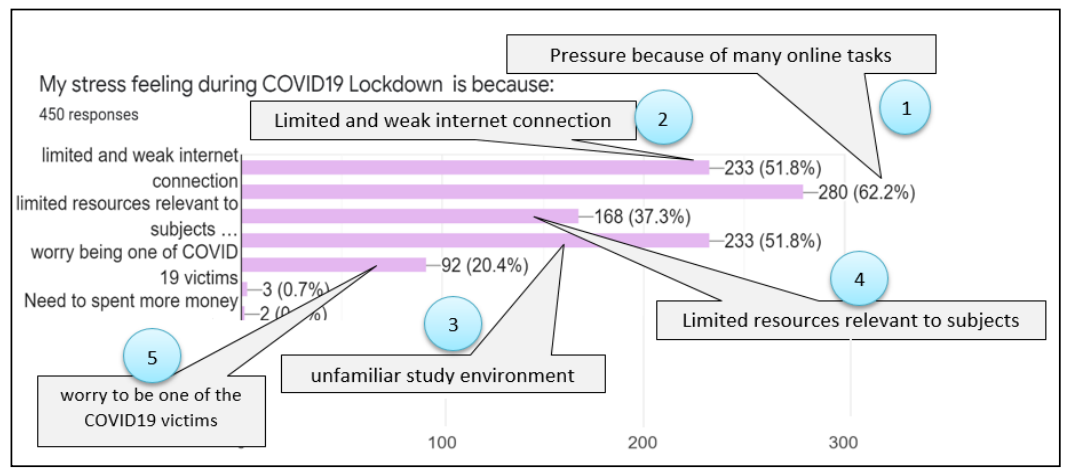

Fig. 8. Major sources of stress among University students during COVID19 pandemic 


\section{Recommendations}

COVID-19 pandemic forced both instructors and students in the higher education institutions (HEIs) to fully adopt different online emerging technologies and platforms that serve online learning and distance education. As a result of sudden full adoption for online learning, students encountered many challenges and obstacles that generate stress and could affect their mental health, personal wellbeing, and academic performance. The following guidelines and recommendations are comprehensively introduced to support further HEIs efforts in minimizing panic among students and to help manage these challenges and obstacles in an effective way:

1. To avoid work overload among students, the institution must inform and help instructors to review and redesign their teaching plans according to the COVID-19 new normal.

2. The institution's top management should provide adequate training and support for instructors and students relevant to the newly emerged online pedagogy and technological tools and platforms.

3. Some online motivational talk sessions must be conducted by institutions through colleges or consultancy department for both students and their families on the best way to deal with new normal.

4. The institution's top management should have an action plan for those students who face difficulty, or who cannot afford to have necessary facilities for online learning.

5. Online learning platforms and emerging technologies adopted for distance education should support the two-way interactivity between students and instructors to insure high level of student's engagement, participation and real presence.

6. Frequent purposive and well-designed online survey should be distributed among students through micro and macro levels of institution's management to measure online learning effectiveness, and to highlight any other hidden social or health related problems among students.

7. Conducting training programs for instructors on then best practices of distance learning.

8. Adapting the teaching strategies and learning outcome measurements that can help to standardize the online tasks given to students in order to reduce the students' stress.

9. Universities need to have comprehensive guidelines for students and lecturers to manage challenges and obstacles in an effective way.

\section{Conclusion}

Universities in particular and many other Higher Education Institutions in general are among many businesses that were affected by the COVID-19 pandemic and new normal. Many instructors and students found themselves fully adopting many online learning platforms and emerging technologies for distance education during COVID- 
19 outbreak, and they will continue to fully use these online platforms until the COVID-19 outbreak ends. As a result, some press, news agencies and some members in education institutions have begun to report about some students' complaints about various problems, unease and challenges they experience when applying full mode of online learning using different emerging technology platforms. Therefore, this study was conducted to gain a deeper understanding of the impact of COVID-19 pandemic on university students' academic life and personal heath from students' perceptions. By collecting and analyzing more than 480 data set about different level of students from more 15 public and private Malaysian Universities, it was found that students are facing number of serious challenges during COVID-19 when they use different online learning platforms. These problems, such as stress and anxiety, are caused by many different sources of challenges such as having too many online tasks, which leads students to face information and work overload, the requirement to spend more hours in front of their computers, lack of motivation and guide for students on how to manage and deal with new normal. Many other related psychological issues could be triggered in student's new normal life due to some family's lack of awareness of the nature of online education. Therefore, Education Institutions must tackle these issues to insure uninterrupted education process and more healthy students for better academic performance and achievements.

\section{$7 \quad$ References}

[1] S. P. Stawicki et al., "The 2019-2020 novel coronavirus (severe acute respiratory syndrome coronavirus 2) pandemic: A joint american college of academic international medicine-world academic council of emergency medicine multidisciplinary COVID-19 working group consensus paper," Journal of Global Infectious Diseases, vol. 12, no. 2, p. 47, 2020. https://doi.org/10.4103/jgid.jgid_86_20

[2] S. N. S. Allam, M. S. Hassan, R. Sultan, A. F. R. Mohideen, and R. M. Kamal, "Online Distance Learning Readiness During Covid-19 Outbreak Among Undergraduate Students," Journal of Academic Research in Business and Social Sciences, vol. 10, no. 5, pp. 642657, 2020. https://doi.org/10.6007/ijarbss/v10-i5/7236

[3] Qureshi MI, Khan N, Gillani SM, Raza H. "A Systematic Review of Past Decade of Mobile Learning: What we Learned and Where to Go.", International Journal of Interactive Mobile Technologies (iJIM), 2020 Apr 17;14(06):67-81. https://doi.org/10.3991 iijim.v14i06.13479

[4] E. Kurilovas and S. Kubilinskiene, "Lithuanian case study on evaluating suitability, acceptance and use of IT tools by students-An example of applying Technology Enhanced Learning Research methods in Higher Education," Computers in Human Behavior, vol. 107, p. 106274, 2020. https://doi.org/10.1016/j.chb.2020.106274

[5] D. S. Hui et al., "The continuing 2019-nCoV epidemic threat of novel coronaviruses to global health-The latest 2019 novel coronavirus outbreak in Wuhan, China," International Journal of Infectious Diseases, vol. 91, pp. 264-266, 2020. https://doi.org/10. 3410/f.737216219.793577187

[6] J. Ma, "Coronavirus: China's first confirmed Covid-19 case traced back to November 17," South China Morning Post, vol. 13, 2020.

[7] B. N. JOAO, "Geographic Information Systems and COVID-19: The Johns Hopkins University Dashboard," 2020. https://doi.org/10.21203/rs.3.rs-15447/v1 
[8] P. Doshi, "The elusive definition of pandemic influenza," Bulletin of the World Health Organization, vol. 89, pp. 532-538, 2011. https://doi.org/10.2471/blt.11.086173

[9] A. Elengoe, "COVID-19 Outbreak in Malaysia," Osong Public Health and Research Perspectives, vol. 11, no. 3, p. 93, 2020. https://doi.org/10.24171/j.phrp.2020.11.3.08

[10] T. Sukumaran, "Coronavirus: Malaysia in partial lockdown from March 18 to limit outbreak" South China Morning Post. 2020 Mar 16; [Internet] Available from: https://www.scmp.com/week-asia/health-environment/article/3075456/coronavirusmalaysias-prime-minister-muhyiddin-yassin.," ed, 2020

[11] J. Bunyan, "PM: Malaysia under movement control order from Wed until March 31, all shops closed except for essential services Posted Monday, 16 Mar 2020 10:24 PM MYT, [Intenret]Available from: https://www.malaymail.com/news/malaysia /2020/03/17/movement-control-order-not-a-lockdown-says-former-healthminister/1847232. ," 2020.

[12] Y. Palansamy, "Higher Education Ministry: All university lectures to be online-only until end 2020, with a few exceptions Posted on Wednesday, 27 May 2020 [Internet] Available from: https://www.malaymail.com/news/malaysia/2020/05/27/higher-education-ministryall-university-lectures-to-be-online-only-until-e/1869975," ed, 2020.

[13] A. Gunasekaran, R. D. McNeil, and D. Shaul, "E-learning: research and applications," Industrial and commercial training, 2002.

[14] H. Kanuka and T. Anderson, "Ethical issues in qualitative e-learning research," International Journal of Qualitative Methods, vol. 6, no. 2, pp. 20-39, 2007.

[15] P.-C. Sun, R. J. Tsai, G. Finger, Y.-Y. Chen, and D. Yeh, "What drives a successful eLearning? An empirical investigation of the critical factors influencing learner satisfaction," Computers \& education, vol. 50, no. 4, pp. 1183-1202, 2008. https://doi.org/10. 1016/j.compedu.2006.11.007

[16] A. Raes, P. Vanneste, M. Pieters, I. Windey, W. Van Den Noortgate, and F. Depaepe, "Learning and instruction in the hybrid virtual classroom: An investigation of students' engagement and the effect of quizzes," Computers \& Education, vol. 143, p. 103682, 2020. https://doi.org/10.1016/j.compedu.2019.103682

[17] Khan N, Qureshi M. "A systematic literature review on online medical services in Malaysia."

[18] T. Triyason, A. Tassanaviboon, and P. Kanthamanon, "Hybrid Classroom: Designing for the New Normal after COVID-19 Pandemic," in Proceedings of the 11th International Conference on Advances in Information Technology, 2020, pp. 1-8. https://doi.org/10.1145/3406601.3406635

[19] G. Ifijeh, "Information explosion and university libraries: Current trends and strategies for intervention," Chinese librarianship: An international electronic journal, 2010.

[20] B. N. Yusuf, "Are we Prepared Enough? A Case Study of Challenges in Online Learning in A Private Higher Learning Institution During The Covid-19 Outbreaks," Advances in Social Sciences Research Journal, vol. 7, no. 5, pp. 205-212, 2020. https://doi.org/10. 14738/assri.75.8211

[21] Khan N, Qureshi M, Mustapha I, Irum S, Arshad R. "A systematic literature review paper on online medical mobile applications in Malaysia."

[22] A. Bozkurt and R. C. Sharma, "Emergency remote teaching in a time of global crisis due to Corona Virus pandemic," Asian Journal of Distance Education, vol. 15, no. 1, pp. i-vi, 2020.

[23] S. N. S. Allam, M. S. Hassan, R. Sultan, A. F. R. Mohideen, and R. M. Kamal, "Online Distance Learning Readiness During Covid-19 Outbreak Among Undergraduate Students," Journal of Academic Research in Business and Social Sciences, vol. 10, no. 5, pp. 642657. https://doi.org/10.6007/ijarbss/v10-i5/7236

[24] A. A. Al-Baadani and M. Abbas, "The impact of Coronavirus (covid19) pandemic on Higher Education Institutions (HEIS) in Yemen: Challenges and recommendations for the 
future," European Journal of Education Studies, vol. 7, no. 7, 2020. https://doi.org/ 10.46827/ejes.v7i7.3152

[25] S. Becker, A. Bryman, and H. Ferguson, Understanding research for social policy and social work: themes, methods and approaches. Policy Press, 2012. https://doi.org/10. 2307/j.ctt1t892hf

[26] U. Flick, An introduction to qualitative research. Sage, 2009.

[27] J. M. Morse, "The Significance of Saturation," Qualitative Health Research, vol. 5, no. 2 \%U http://qhr.sagepub.com/content/5/2/147.short, pp. 147-149, 1995.

[28] A. J. Onwuegbuzie and N. L. Leech, "Sampling designs in qualitative research: Making the sampling process more public," The qualitative report, vol. 12, no. 2, pp. 238-254\%@ 1052-0147, 2007.

[29] R. Sunasee, "Challenges of Teaching Organic Chemistry during COVID-19 Pandemic at a Primarily Undergraduate Institution," Journal of Chemical Education, 2020. https://doi.org/10.1021/acs.jchemed.0c00542

[30] A. Ben-Chayim and B. Offir, "Model of the Mediating Teacher in Distance Learning Environments: Classes That Combine Asynchronous Distance Learning via Videotaped Lectures," Journal of Educators Online, vol. 16, no. 1, p. n1, 2019. https://doi.org/10. 9743/jeo.2019.16.1.1

[31] O. F. VURAL, "Positive and negative aspects of using social networks in higher education: A focus group study," Educational Research and Reviews, vol. 10, no. 8, pp. 1147-1166, 2015.

[32] A. Andrade, C. Castro, and S. A. Ferreira, "Cognitive Communication 2.0 in Higher Education: To Tweet or Not to Tweet?" Electronic Journal of E-Learning, vol. 10, no. 3, pp. 293-305, 2012.

[33] S. Manca and M. Ranieri, "Facebook and the others. Potentials and obstacles of social media for teaching in higher education," Computers \& Education, vol. 95, pp. 216-230, 2016. https://doi.org/10.1016/j.compedu.2016.01.012

[34] P. S. Goodman and D. P. Leyden, "Familiarity and group productivity," Journal of applied psychology, vol. 76, no. 4, p. 578, 1991.

[35] A. Espinosa, R. Kraut, S. Slaughter, J. Lerch, J. Herbsleb, and A. Mockus, "Shared mental models, familiarity, and coordination: A multi-method study of distributed software teams," ICIS 2002 Proceedings, p. 39, 2002.

[36] J. Maeda, The laws of simplicity. MIT press, 2006.

[37] M. Trier and A. Richter, "' I Can Simply..."-Theorizing Simplicity as A Design Principle and Usage Factor," 2013.

[38] M.-C. Lee, "Software quality factors and software quality metrics to enhance software quality assurance," Current Journal of Applied Science and Technology, pp. 3069-3095, 2014. https://doi.org/10.9734/bjast/2014/10548

[39] P. Maurice, M. Lavoie, L. Laflamme, L. Svanström, C. Romer, and R. Anderson, "Safety and safety promotion: definitions for operational developments," Injury Control and Safety Promotion, vol. 8, no. 4, pp. 237-240, 2001. https://doi.org/10.1076/icsp.8.4. $\underline{237.3331}$

[40] M. Bartsch and T. Dienlin, "Control your Facebook: An analysis of online privacy literacy," Computers in Human Behavior, vol. 56, pp. 147-154, 2016. https://doi.org/10.1016/ j.chb.2015.11.022

[41] K. L. G. Romas, M. Y. B. de Robles, and J. P. Pabico, "Design, Implementation, and Evaluation of a 3D Virtual Classroom Environment in a Computer Cluster," ISCE 2014 Proceedings, p. 68, 2014.

[42] C. J. Bonk and C. R. Graham, The handbook of blended learning: Global perspectives, local designs. John Wiley \& Sons, 2012.

[43] T. B. Battaglino, M. Haldeman, and E. Laurans, "The costs of online learning," Education reform for the digital era, vol. 1, pp. 1-13, 2012. 
[44] A. Kenny, "Online learning: enhancing nurse education?" Journal of Advanced Nursing, vol. 38, no. 2, pp. 127-135, 2002.

[45] T. Nguyen, "The effectiveness of online learning: Beyond no significant difference and future horizons," MERLOT Journal of Online Learning and Teaching, vol. 11, no. 2, pp. 309-319, 2015.

[46] J. Pilcher and D. A. Bradley, "Best practices for learning with technology," Journal for nurses in professional development, vol. 29, no. 3, pp. 133-137, 2013. https://doi.org/10. 1097/nnd.0b013e318291c220

[47] E. Costello et al., "Information and communication technology to facilitate learning for students in the health professions: Current uses, gaps, and future directions," Online learning: Official Journal of the Online Learning Consortium, vol. 18, 2014. https://doi.org/10. 24059/olj.v18i4.512

[48] S. Schullo, A. Hilbelink, M. Venable, and A. E. Barron, "Selecting a virtual classroom system: Elluminate live vs. Macromedia breeze (adobe acrobat connect professional)," MERLOT Journal of Online Learning and Teaching, vol. 3, no. 4, pp. 331-345, 2007.

[49] A. M. Al-Shehri, "The development of reusable online learning resources for instructional design students based on the principles of learning objects," Kansas State University, 2004.

[50] M. Wang, C. Xu, X. Chen, H. Hao, L. Zhong, and S. Yu, "Differential privacy oriented distributed online learning for mobile social video prefetching," IEEE Transactions on Multimedia, vol. 21, no. 3, pp. 636-651, 2019. https://doi.org/10.1109/tmm.2019.289 $\underline{2561}$

[51] J. B. Williams and J. Jacobs, "Exploring the use of blogs as learning spaces in the higher education sector," Australasian journal of educational technology, vol. 20, no. 2, 2004. https://doi.org/10.14742/ajet.1361

[52] E. L. Meyen et al., "e-Learning: A programmatic research construct for the future," Journal of Special Education Technology, vol. 17, no. 3, pp. 37-46, 2002.

[53] A. Dailey-Hebert, "Maximizing interactivity in online learning: Moving beyond discussion boards," Journal of Educators Online, vol. 15, no. 3, p. n3, 2018. https://doi.org/10. 9743/jeo.2018.15.3.8

[54] J.-N. Sun and Y.-C. Hsu, "Effect of interactivity on learner perceptions in Web-based instruction," Computers in Human Behavior, vol. 29, no. 1, pp. 171-184, 2013. https://doi.org/10.1016/j.chb.2012.08.002

[55] F. Martin, M. A. Parker, and D. F. Deale, "Examining interactivity in synchronous virtual classrooms," International Review of Research in Open and Distributed Learning, vol. 13, no. 3, pp. 227-261, 2012. https://doi.org/10.19173/irrodl.v13i3.1174

[56] W. M. Al-rahmi, M. S. Othman, and L. M. Yusuf, "Using social media for research: The role of interactivity, collaborative learning, and engagement on the performance of students in Malaysian post-secondary institutes," Mediterranean Journal of Social Sciences, vol. 6, no. 5, p. 536, 2015. https://doi.org/10.5901/mjss.2015.v6n5s2p536

[57] K. Zhao, Q. Yang, and X. Ma, "Exploration of an open online learning platform based on google cloud computing," International Journal of Emerging Technologies in Learning (iJET), vol. 12, no. 07, pp. 17-31, 2017. https://doi.org/10.3991/ijet.v12i07.7249

[58] A. Wang and L. H. Huang, "E-learning exploration based on cloud computing," in Applied Mechanics and Materials, 2013, vol. 333, pp. 2226-2230: Trans Tech Publ.

[59] A. Y. Mjhool, A. H. Alhilali, and S. Al-Augby, "A proposed architecture of big educational data using hadoop at the University of Kufa," International Journal of Electrical and Computer Engineering, vol. 9, no. 6, p. 4970, 2019. https://doi.org/10.11591/ ijece.v9i6.pp4970-4978

[60] G. Amvrosiadis, A. R. Butt, V. Tarasov, E. Zadok, and M. Zhao, "Data storage research vision 2025 report," Technical Report, 2019.

[61] T. Hirave, A. Khan, S. Surve, and S. Malgaonkar, "Data Analytics Research Agenda: ELearning \& its Integration with Other Platforms," in 2018 Fourth International Conference 
on Computing Communication Control and Automation (ICCUBEA), 2018, pp. 1-6: IEEE. https://doi.org/10.1109/iccubea.2018.8697405

[62] K.-O. Jeong, "A study on the integration of Google Docs as a web-based collaborative learning platform in EFL writing instruction," Indian Journal of Science and Technology, vol. 9, no. 39, pp. 1-7, 2016. https://doi.org/10.17485/ijst/2016/v9i39/103239

[63] R. Panigrahi, P. R. Srivastava, and D. Sharma, "Online learning: Adoption, continuance, and learning outcome-A review of literature," International Journal of Information Management, vol. 43, pp. 1-14, 2018. https://doi.org/10.1016/j.ijinfomgt.2018.05.005

[64] X. Lin and L. Gao, "Students' sense of community and perspectives of taking synchronous and asynchronous online courses," Asian Journal of Distance Education, vol. 15, no. 1, pp. 169-179, 2020.

[65] I. Lim, "Reality for Malaysia's university students: Online learning challenges, stress, workload; possible solutions for fully digital future until Dec Posted Monday, 16 Mar 2020 10:24 PM MYT, [Internet] Available from: https://www.malaymail.com/news/malaysia /2020/05/30/reality-for-malaysias-university-students-online-learning-challengesstress/1870717," ed, 2020.

[66] S. Menon, "Students anxious but ready to see it through posted on Wednesday, 15 Apr 2020 [Internet] Available from: https://www.thestar.com.my/news/nation /2020/04/15/students-anxious-but-ready-to-see-it-through," ed, 2020.

[67] W. Bao, "COVID-19 and online teaching in higher education: A case study of Peking University. Human Behavior and Emerging Technologies, 2 (2), 113-115," ed, 2020. https://doi.org/10.1002/hbe2.191

[68] C. Wang and H. Zhao, "The Impact of COVID-19 on Anxiety in Chinese University Students," Frontiers in Psychology, vol. 11, p. 1168, 2020.

[69] N. Ozamiz-Etxebarria, M. Dosil-Santamaria, M. Picaza-Gorrochategui, and N. IdoiagaMondragon, "Stress, anxiety, and depression levels in the initial stage of the COVID-19 outbreak in a population sample in the northern Spain," Cadernos de Saúde Pública, vol. 36, p. e00054020, 2020. https://doi.org/10.1590/0102-311x00054020

\section{Authors}

Nabil Hasan Al-Kumaim, Faculty of Technology Management and Technopreneurship, Center of Technopreneurship Development (CTeD), Universiti Teknikal Malaysia Melaka (UTeM) Melaka, Malacca, Malaysia. Email: nabil@utem.edu.my

Fathey Mohammed, School of Computing, Universiti Utara Malaysia (UUM), 06010 Sintok, Kedah Darul Aman, Malaysia.

Nadhmi A. Gazem, Department of Information System, College of Business Administration-Yanbu, Taibah University Medina 42353, Saudi Arabia

Yousef Fazea, Internetworks Research, School of Computing, Universiti Utara Malaysia, Sintok, 06010 Kedah, Malaysia

Abdulsalam K. Alhazmi, Faculty of Electronic and Distance Learning, University of Science and Technology, Aden, Yemen

Omar Dakkak, Faculty of Engineering, Department of Computer Engineering, Karabük University,78050, Karabük, Turkey

Article submitted 2020-12-01. Resubmitted 2021-01-26. Final acceptance 2021-01-26. Final version published as submitted by the authors. 